\title{
SALICYLATES AND THYROID FUNCTION. I. DEPRESSION OF THYROID FUNCTION
}

\author{
By FRANK K. AUSTEN, MILTON E. RUBINI, WILLIAM H. MERONEY, AND \\ J. WOLFF \\ (From the Department of Metabolism, Walter Reed Institute of Research and Walter Reed \\ Army Hospital, Washington, D. C., and the National Institute of Arthritis and \\ Metabolic Diseases, National Institutes of Health, Bethesda, Md.)
}

(Submitted for publication February 4, 1958; accepted April 10, 1958)

In 1916 Denis and Means (1) first observed that salicylate administration increased oxygen consumption and carbon dioxide production in man. This finding has since been confirmed both in man $(2,3)$ and in experimental animals $(4-6)$. Although salicylates increase the resting minute ventilation, it has been demonstrated that the elevation in basal metabolic rate is not dependent on an increase in respiratory work. Decapitated or curarized dogs maintained in a total body respirator to keep ventilation constant showed the same increased oxygen consumption in response to salicylate administration as the intact animal (5). Furthermore, oxygen consumption has been shown to be increased in tissues removed from salicylatetreated animals (7) and in isolated tissue or mitochondrial preparations to which salicylates have been added $(8,9)$. The increase in oxygen consumption is accompanied by a reduction in the esterification of inorganic phosphate, i.e., salicylates uncouple oxidative phosphorylation (7).

The administration of 2,4-dinitrophenol to man or animals leads to strikingly similar alterations. Basal metabolic rate is increased in the intact animal (10-12), tissue oxygen consumption is stimulated in slices (13), and oxidative phosphorylation is uncoupled in isolated mitochondrial preparations $(14,15)$. Indeed, several authors have commented on the similarity of 2,4-dinitrophenol and salicylate $(6,8,16)$.

It has recently been shown that 2,4-dinitrophenol produces a generalized depression of thyroid function in rats $(13,17,18)$ and reduces the serum protein bound iodine concentration (PBI) in rats (17) and man (19). The toxicity of 2,4dinitrophenol (12) precludes a thorough study of its effect on thyroid function in man. Salicylates, on the other hand, are well suited for such an investigation and preliminary studies (20) showed that salicylate administration increased the metabolic rate while simultaneously depressing thyroid function.

\section{MATERIAL AND METHODS}

The effect of salicylate administration on thyroid function was studied in 25 male patients ranging in age from 18 to 38 years. Twenty had rheumatoid arthritis; and five were hospitalized for other conditions-myxedema, gout, acne, and two for chronic otitis media. Balance studies were performed in a metabolic unit. Nineteen patients participated in studies of the effect of chronic salicylate therapy and received salicylates for 8 to 15 weeks, and six took part in acute studies during which salicylates were given for 7 to 10 days. No other medications except an occasional sedative were permitted; daily physical therapy was encouraged. Six of the patients participating in the chronic studies had an elevated erythrocyte sedimentation rate at the beginning of the study.

Enteric coated sodium salicylate was given every four hours. In long term studies the initial dose of $6.0 \mathrm{Gm}$. per day was gradually increased, reaching $8.1 \mathrm{Gm}$. in certain instances. In the acute experiments $9.0 \mathrm{Gm}$. was administered daily throughout the study. Serum "salicyl" (salicylate and salicylurate) concentration (21) was measured at weekly intervals, or more frequently if the study was short.

The basal metabolic rate was determined three or more times before and/or after salicylate administration, at weekly intervals during chronic salicylate therapy, and more frequently during acute experiments. The patients were fasted 12 hours and slept in a secluded room. Oxygen consumption was measured using the closed circuit technique and basal metabolic rate was obtained from factor tables. ${ }^{1}$

Twenty-four hour urine samples were collected for creatinine and creatine determinations (22). ${ }^{2}$ Standard

\footnotetext{
1 Operation Manual for Model 10 Sanborn Metabulator, 1952.

2 It was found that the addition of salicylate or gentisate to urine in amounts approximating their estimated urine concentration significantly increased the apparent urine creatine value. Since the false positive effect of gentisate was 30 to $\mathbf{4 0}$ times as great as that of salicylate on a molar basis and the conversion to gentisate ranges
} 
methods were employed for the measurement of serum cholesterol $(25,26)$. The addition of salicylate to normal sera to a concentration of $45 \mathrm{mg}$. per $100 \mathrm{ml}$. did not interfere with the protein bound iodine determination by the method of Barker, Humphrey, and Soley (27).$^{3}$

In the studies of thyroxine disappearance, $\mathrm{I}^{131}$-labeled L-thyroxine ${ }^{4}$ was injected intravenously in doses ranging from 25 to 75 microcuries with a specific activity of 14 to 29 microcuries per microgram. Prior to injection the radiothyroxine was diluted with human serum albumin 5 to diminish absorption on the syringe and glassware used to prepare the standard. Serum samples collected 10 minutes after injection and each morning were counted in a well-type scintillation counter. When observations were desired for more than 15 days, counting was done with a specially shielded differential pulse height analyzer. Slopes were determined on the basis of a minimum of eight daily points. Half-life, turnover rate, pool size, and degradation rate were calculated as by Sterling, Lashof, and Man (28). Thyroxine binding by serum protein was measured by the reverse flow zone electrophoresis method of Robbins (29).

The radioiodine uptake was determined following an oral tracer dose of 7.5 to 10 microcuries of carrier-free $\mathrm{I}^{131}$. The thyroid region was counted at 2, 5 and 24 hours with a wide angle scintillation counter at a distance of $15 \mathrm{~cm}$; body background was estimated by counting over the thigh. No subject received more than a cumulative total of 125 microcuries of $\mathrm{I}^{182}$.

During the measurement of thyroid and renal clearance of radioiodine urine flow was maintained by sustained water diuresis at 8 to $15 \mathrm{ml}$. per minute to minimize urinary dead space and facilitate complete collections. Urine was obtained by spontaneous voiding 35 minutes after injection of radioiodine and every half hour thereafter. Blood was collected through an indwelling brachial vein catheter during the second and fifteenth minute and, subsequently, at half-hour intervals from the time of radioiodine injection. The thyroid region was counted each minute during the first five minutes and, thereafter, for a five minute period at half-hour intervals from the time of injection. Samples of plasma, urine, and an aliquot of the administered radioiodine were counted together at the end of the experiment. A plot of the logarithm of plasma radioactivity against time yielded a straight line 30 to 45 minutes after injection.

The renal clearance of radioiodine at half-hour intervals was computed using the mean plasma radioactivity as described by Keating and co-workers (30). The thyroid clearance was calculated from the rate of accumu-

from 1 to 8 per cent $(23,24)$ accurate correction to obtain true creatine values could not be made. Nevertheless, the estimated error, assuming a 10 per cent conversion, did not account for the creatinuria observed in most patients.

${ }^{3}$ Performed by the Bioscience Laboratories, Los Angeles, Calif.

4 Supplied by Abbott Laboratories, Oak Ridge, Tenn.

5 Supplied by Armour Laboratories, Chicago, Ill. lation of radioiodine during a given interval divided by the mean plasma radioactivity. The neck counts were corrected for extrathyroidal radioactivity by assuming that all the neck radioactivity at two minutes was extrathyroidal and that it decreased proportionally to the falling plasma radioactivity. From the ratio of the neck to plasma radioactivity during the second minute and the plasma radioactivity at any subsequent time, the extrathyroidal radioactivity at that time was estimated. Thus, the thyroidal clearance of iodide in $\mathrm{ml}$. per minute is :

$$
\mathrm{CI}^{131}=\frac{\mathrm{N}_{2}-\mathrm{N}_{1}}{\mathrm{~T} \times \mathrm{P}}
$$

where $\mathrm{N}$ equals corrected neck counts per minute at times $t_{1}$ and $t_{2} ; P$ equals plasma counts per minute per $\mathrm{ml}$. calculated as the mean of a function between $t_{1}$ and $t_{2}$ (30); and $T$ equals time interval in minutes between $t_{1}$ and $t_{\text {.. }}$.

The effect of salicylate on the iodide concentrating mechanism of the thyroid was studied according to standard procedure (18). Male Sprague-Dawley rats maintained on a low iodine diet for three to six weeks were given an intraperitoneal injection of $10 \mathrm{mg}$. of 1-methyl2-mercaptoimidazole. Forty-five minutes later 30 to 50 mg. of sodium salicylate or $20 \mathrm{mg}$. of sodium thiocyanate was injected, followed in 20 minutes by 1 microcurie of carrier-free $\mathrm{I}^{131}$. The rats were sacrificed one hour later, and the radioactivity of the thyroid gland and plasma was determined.

Thyroidal organification of iodide was studied in vitro (31) using thyroids from male Sprague-Dawley rats kept on a low iodine diet for 26 days. Thyroid lobes were sectioned free hand and incubated under an atmosphere of oxygen in Krebs-Ringer phosphate medium, $\mathrm{pH}$ 7.4. Known concentrations of 1-methyl-2-mercaptoimidazole or sodium salicylate and carrier-free $\mathrm{I}^{131}$ were added to the medium. After three hours the slices were blotted, homogenized in cold 10 per cent trichloroacetic acid, and washed twice with cold 5 per cent trichloroacetic acid. Radioactivity of the precipitate ("organic $I^{131}$ ") and of an aliquot of the combined supernatant fractions (trichloroacetic acid soluble fraction) was determined. The combined radioactivity constituted total "uptake."

\section{RESULTS AND DISCUSSION}

The increase in oxygen consumption produced by salicylate administration ( $c f$. below) was not accompanied by an elevation in the rectal temperature or a complaint of heat intolerance, although on questioning some patients were aware of increased sweating. Hyperkinesis and emotional lability were lacking, and, in fact, several patients became lethargic and slept much of the time. Neither the waking nor the sleeping pulse rate increased during the acute or protracted studies. The patient with myxedema experienced a rise in basal metabolic rate from minus 35 to plus 35 per 
cent without an increment in pulse rate. Similarly, in two thyrotoxic patients with a tachycardia while sleeping, salicylates failed to increase the pulse rate while further elevating the basal metabolic rate.

The mean serum salicylate level in 16 patients receiving salicylates for 8 to 15 weeks was $37 \mathrm{mg}$. per $100 \mathrm{ml}$., ranging from 22 to $47 \mathrm{mg}$. per 100 ml. In two other patients, C. M. and L. E., the concentration was maintained at 65 and $58 \mathrm{mg}$. per cent, respectively. One-third of the patients receiving salicylates chronically complained of tinnitus or diminished auditory acuity early in the treatment period, but soon became adapted and tolerated even larger doses. None of the group receiving salicylates for a protracted period was troubled by nausea or vomiting, and there were no instances of a bleeding tendency. A twofold increase in resting minute ventilation occurred in Patients C.M. and L. E., and in two other patients, K. C. and W. C., whose serum salicylate concentration exceeded $50 \mathrm{mg}$. per $100 \mathrm{ml}$. near the end of the study period. The serum bicarbonate was reduced 5 to $7 \mathrm{mEq}$. per liter in these patients, but the venous $\mathrm{pH}$ was not predictable, being normal, slightly elevated, or slightly depressed. The remaining patients on chronic salicylate therapy showed a mean increase of 65 per cent in resting minute ventilation, 9 per cent in respiratory rate, and 52 per cent in tidal volume, and they maintained their serum bicarbonate concentration and $\mathrm{pH}$ within the normal range.

\section{Oxygen consumption}

The average individual increase in oxygen consumption ranged from 41 to $104 \mathrm{ml}$. per min. per $1.73 \mathrm{M} .^{2}$, and the mean increase for the group was $73 \mathrm{ml}$. per min. per $1.73 \mathrm{M}^{2}$ (Table I). This is

TABLE I

The effect of chronic salicylate administration on oxygen consumption

\begin{tabular}{ccc}
\hline \multicolumn{3}{c}{ Mean oxygen consumption in ml. per min. per 1.73 M.2 } \\
\cline { 2 - 3 } Control (12)* & $\begin{array}{c}\text { Salicylate ad- } \\
\text { ministration (16) }\end{array}$ & Postcontrol (15) \\
\hline $221 \pm 16 \dagger$ & $294 \pm 23$ & $222 \pm 16$ \\
\hline
\end{tabular}

* Figures in parentheses refer to number of patients studied. The mean serum salicylate concentration was $37 \pm 7 \mathrm{mg}$. per $100 \mathrm{ml}$. (mean plus or minus standard deviation). equivalent to a mean rise in basal metabolic rate from a level of minus 8 to plus 22 per cent. The elevation in oxygen consumption appeared during the first 24 hours of salicylate therapy. This was documented in seven subjects in whom the increase in oxygen consumption ranged from 42 to $130 \mathrm{ml}$. per min. per $1.73 \mathrm{M} .^{2}$ after 24 hours.

The relation of the increase in oxygen consumption to the serum salicylate concentration in 16 patients on chronic salicylate therapy is depicted in Figure 1. The coefficient of correlation ( $r$ ) is $0.72(p<0.01)$. A similar relationship has been observed in rabbits (6) and in patients with myxedema (32). The two patients, C. M. and L. E., whose mean salicylate concentrations were 65 and $58 \mathrm{mg}$. per $100 \mathrm{ml}$., respectively, were lethargic and failed to show a rise in oxygen consumption proportional to their serum salicylate concentration; their points lie to the right of the regression line shown in Figure 1. In contrast,

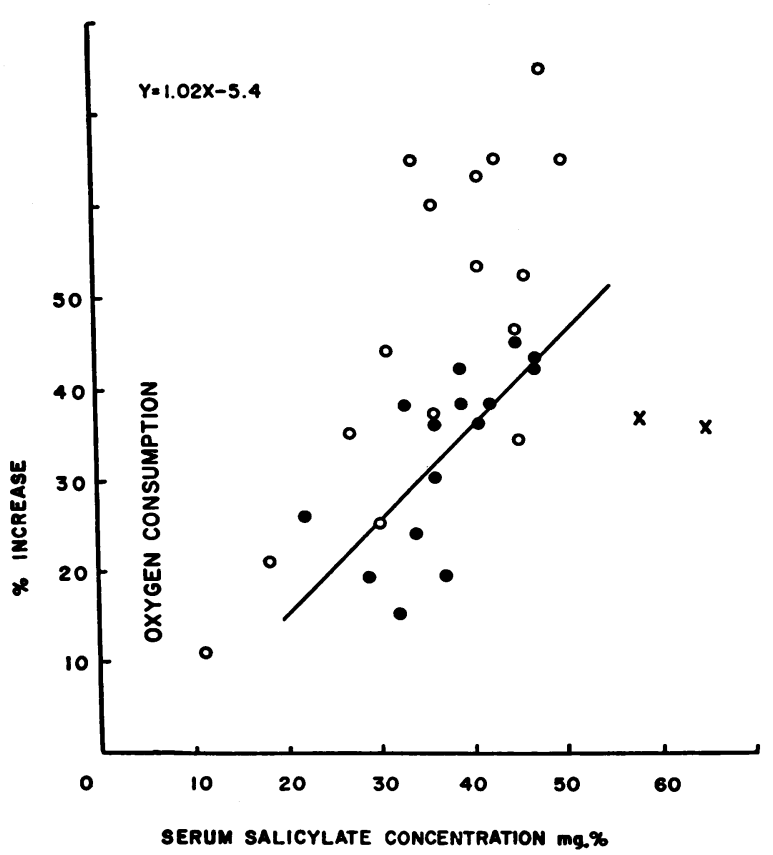

Fig. 1. Correlation of Oxygen Consumption and Serum Salicylate Concentration

The solid circles represent the mean values during the entire period of salicylate administration, and the regression line is the best fit line through these points by the method of least squares. The coefficient of correlation $(r)$ is $0.72(p<0.01)$. The open circles represent single values obtained during the first 3 to 10 days of salicylate administration. The crosses illustrate the findings in Patients C. M. and L. E. (see text). 


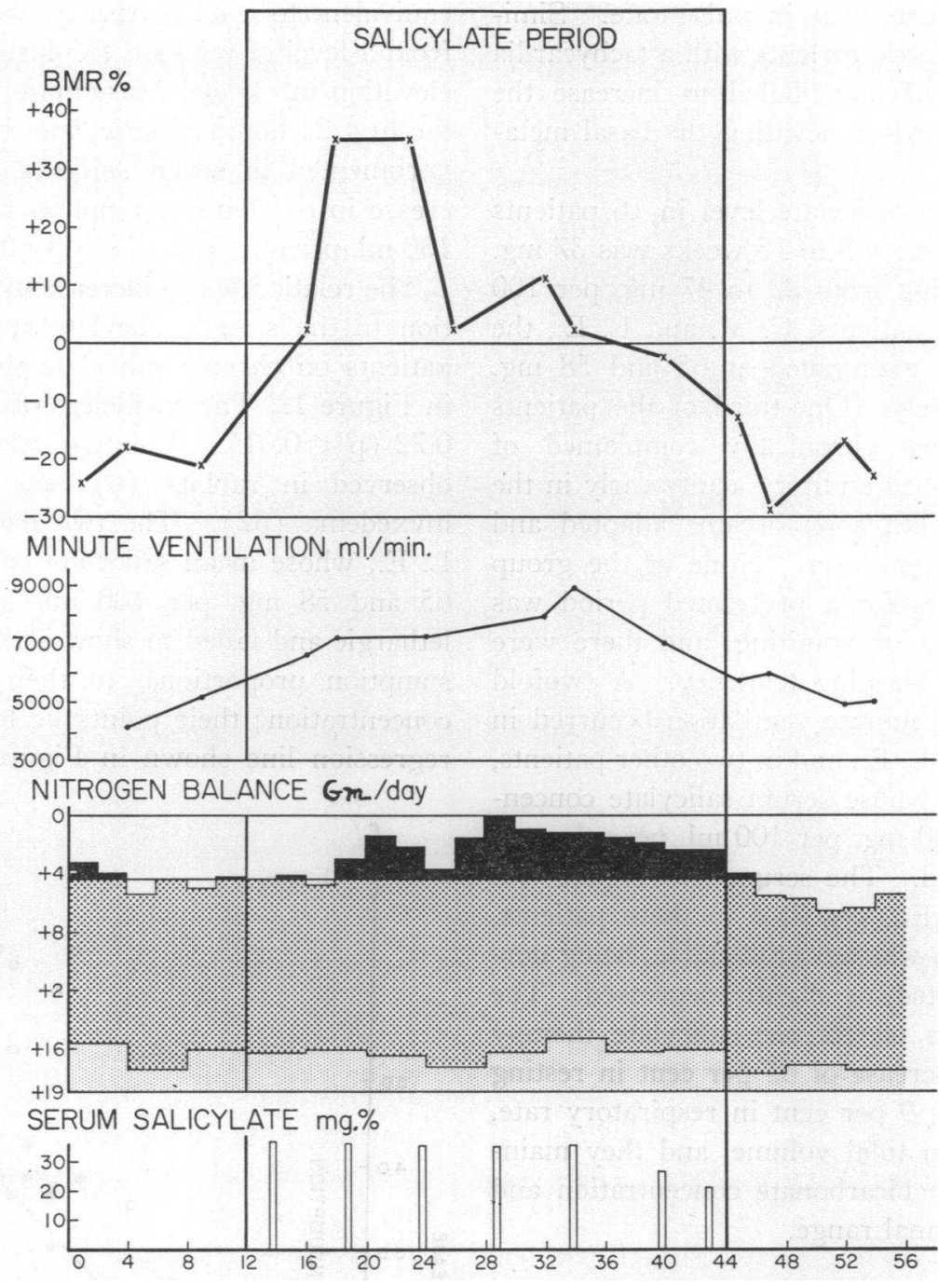

Fig. 2. Effect of Salicylate Administration in Myxedema

The increase in basal metabolic rate falls off somewhat after the first 10 days although the serum salicylate concentration remains unchanged. The rise in BMR is not dependent on the increase in resting minute ventilation. The light hatching represents stool nitrogen; the black area indicates the reduction in nitrogen retention during salicylate administration as compared to the average nitrogen retention of the control period.

the metabolic stimulation for a given serum salicylate concentration was greater during the first 3 to 10 days than during subsequent chronic administration and points obtained during this period fall to the left of the regression line. This suggests some tolerance to the metabolic stimulation of salicylates.

The association of the salicylate-induced increase in oxygen consumption with a reduction in nitro- gen retention was observed in several patients. Nitrogen retention was diminished $2.0 \mathrm{Gm}$. per day as compared to the control period in the patient with myxedema, and the retention in the postsalicylate period exceeded that of the control period (Figure 2). Patients L. E. and C. M. experienced a negative nitrogen balance of 16 and $22 \mathrm{Gm}$. and a weight loss of 5 and 12 pounds, respectively, during 32 days of salicylate administra- 
tion. Similar results have also been obtained in other euthyroid patients maintained at lesser serum salicylate levels (33).

\section{Cholesterol}

A consistent reduction in the total serum cholesterol was noted in only 2 of 16 patients in whom the cholesterol was followed weekly during chronic salicylate administration, and in these 2 patients the decrease was only $50 \mathrm{mg}$. per $100 \mathrm{ml}$. compared to the pre- and postsalicylate administration values. In the patient with myxedema the serum cholesterol fell gradually from 240 to $160 \mathrm{mg}$. per $100 \mathrm{ml}$. in 32 days and rose when salicylate administration was discontinued. Alexander and Johnson (34) have also observed a fall in serum cholesterol in three patients with myxedema during 16 days of salicylate treatment. The failure to induce a fall in the serum cholesterol of the euthyroid patients is similar to the findings obtained with 2,4-dinitrophenol (10). Furthermore, other workers (35) have shown that although thyroid is partially effective against the hypercholesterolemia induced by cholesterol feeding in the chick, dinitrophenol has little or no effect on the plasma or tissue levels of cholesterol and offers no protection against the cholesterol-induced atherosclerosis.

\section{Protein bound iodine (PBI) concentration}

A reduction in the PBI was observed in every patient during salicylate administration (Table II), and the mean decrease was about 30 per cent of the initial value. The maximum reduction in PBI was generally achieved during the first week. No further diminution was obtained by continuing salicylate administration for 8 to 15 weeks or by increasing the maintenance dose from 7.2 to 9.0 $\mathrm{Gm}$. per day. Correlation of the decrease in PBI with the serum salicylate concentration or the mean increase in oxygen consumption is not statistically significant $(r=0.34$ and 0.32 , respectively, $\mathrm{p}>$ $0.10)$. The fall in PBI produced by salicylate administration is similar to that observed in the rat (17) and in man (19) after 24 and 48 hours of 2,4-dinitrophenol treatment, respectively.

\section{Radiothyroxine}

The reduction in PBI concomitant with salicylate administration could result from either a de-
TABLE II

The effect of chronic salicylate administration on the serum protein bound iodine (PBI)

\begin{tabular}{|c|c|c|c|c|}
\hline \multirow[b]{2}{*}{ Patient } & \multirow[b]{2}{*}{$\underset{\mathrm{PBI}}{\text { Control }}$} & \multicolumn{2}{|c|}{$\begin{array}{c}\text { Salicylate } \\
\text { period PBI }\end{array}$} & \multirow{2}{*}{$\begin{array}{c}\text { Post- } \\
\text { contro } \\
\text { PBI }\end{array}$} \\
\hline & & $\begin{array}{c}\text { Fourth } \\
\text { week }\end{array}$ & $\begin{array}{l}\text { Ninth } \\
\text { week }\end{array}$ & \\
\hline & $\mu g . \%$ & \multicolumn{2}{|c|}{$\mu g . \%$} & $\mu g . \%$ \\
\hline K. C. & 5.5 & 4.1 & 4.1 & 5.4 \\
\hline R. P. & 5.9 & 3.7 & 3.7 & 5.8 \\
\hline F. C. & 5.6 & 3.7 & 3.1 & 4.8 \\
\hline$\dot{\mathrm{W}} . \dot{\mathrm{C}}$. & 5.0 & 3.6 & 3.2 & 4.5 \\
\hline J. B. & 6.2 & 4.5 & 4.6 & 6.2 \\
\hline R. B. & 5.7 & 4.4 & 5.0 & \\
\hline F. K. & 4.9 & 3.1 & & 5.4 \\
\hline C. M. & 4.8 & 3.4 & & 4.6 \\
\hline T. $\mathbf{K}$. & 6.8 & 3.9 & 4.5 & 7.0 \\
\hline L. E. & $\begin{array}{l}5.1 \\
47\end{array}$ & $\begin{array}{l}3.7 \\
40\end{array}$ & 37 & $\begin{array}{l}6.4 \\
4.5\end{array}$ \\
\hline C. C. & & 3.7 & 3.3 & 5.4 \\
\hline J. L. & & 3.3 & 3.9 & 5.0 \\
\hline G. D. & & 3.9 & 4.4 & 5.6 \\
\hline \multirow{2}{*}{$\begin{array}{l}\text { Mean } \\
\text { Standard } \\
\text { deviation }\end{array}$} & 5.5 & 3.8 & 4.0 & 5.4 \\
\hline & 0.6 & 0.3 & 0.6 & 0.7 \\
\hline
\end{tabular}

crease in production or an increase in peripheral degradation of thyroid hormone, or both. The observation that dinitrophenol diminished the PBI in a thyroidectomized patient receiving desiccated thyroid (19) suggested that increased peripheral utilization might be an important factor. Earlier studies with dinitrophenol in the rat had shown that this drug caused an increase in the fractional rate of disappearance of radiothyroxine from the circulation (18).

The effect of chronic salicylate therapy on the fractional rate of thyroxine disappearance and degradation was studied in 15 patients (Table III, $a, b$ and c). The average half-life of radiothyroxine was 6.2 and 6.4 days during the preand postsalicylate period, respectively, and fell to 4.7 days during salicylate administration. As a consequence, the turnover rate $^{6}$ rose from 11.3 per cent per day in the precontrol period to 15.1 per cent per day during salicylate treatment and

6 Turnover rate is here defined as the fractional rate of renewal of the extrathyroidal organic iodine pool (EOI) per unit time. In calculating turnover rate it was assumed that the PBI did not change during the experimental period, that PBI is equivalent to thyroxine, and that the serum radioactivity represented thyroxine. PBI determinations before and after the experimental period and chromatograms of the serum supported the first and last of these assumptions. 
TABLE IIIA

Radiothyroxine disappearance in patients with rheumatoid arthritis prior to salicylate administration

\begin{tabular}{|c|c|c|c|c|c|c|}
\hline \multirow[b]{2}{*}{ Subject } & \multirow[b]{2}{*}{ Weight } & \multirow[b]{2}{*}{ PBI } & \multicolumn{2}{|c|}{$\begin{array}{c}\text { Kinetics of } \\
\text { disappearance* }\end{array}$} & \multirow{2}{*}{$\begin{array}{l}\text { Extrathyroidal } \\
\text { organic iodine } \\
\text { pool (EOI) }\end{array}$} & \multirow{2}{*}{$\begin{array}{c}\text { Degradation } \\
\text { rate }\end{array}$} \\
\hline & & & t $1 / 2$ & $k$ & & \\
\hline $\begin{array}{l}\text { W. C. } \\
\text { J. B.† } \\
\text { R. B. } \\
\text { F. K. } \\
\text { C. M. } \\
\text { T. K. } \dagger \\
\text { L. E. } \\
\text { R. Pi. }\end{array}$ & $\begin{array}{l}\text { Kg. } \\
58.2 \\
81.4 \\
57.2 \\
79.5 \\
87.3 \\
53.6 \\
63.6 \\
73.6\end{array}$ & $\begin{array}{l}\mu g . \% \\
5.0 \\
6.6 \\
6.0 \\
4.5 \\
5.0 \\
6.9 \\
5.2 \\
4.9\end{array}$ & $\begin{array}{l}\text { days } \\
5.9 \\
6.2 \\
6.6 \\
7.3 \\
5.6 \\
5.9 \\
6.0 \\
6.1\end{array}$ & $\begin{array}{l}\text { \%/day } \\
11.8 \\
11.2 \\
10.5 \\
9.5 \\
12.4 \\
11.8 \\
11.6 \\
11.4\end{array}$ & $\begin{array}{c}\text { Mg. } / 1.73 M .2 \\
516 \\
732 \\
696 \\
508 \\
548 \\
700 \\
590 \\
497\end{array}$ & $\begin{array}{c}\text { Mg./1.73 M.2/day } \\
61 \\
82 \\
73 \\
48 \\
68 \\
83 \\
68 \\
57\end{array}$ \\
\hline \multicolumn{2}{|c|}{$\begin{array}{l}\text { Mean } \\
\text { Standard deviation }\end{array}$} & $\begin{array}{l}5.5 \\
0.8\end{array}$ & $\begin{array}{l}6.2 \\
0.5\end{array}$ & $\begin{array}{r}11.3 \\
0.8\end{array}$ & $\begin{array}{r}598 \\
90\end{array}$ & $\begin{array}{l}68 \\
11\end{array}$ \\
\hline \multicolumn{2}{|c|}{$\begin{array}{l}\text { Mean (controls) } \ddagger \\
\text { Standard deviation }\end{array}$} & $\begin{array}{l}5.8 \\
0.7\end{array}$ & $\begin{array}{l}6.8 \\
1.0\end{array}$ & $\begin{array}{r}10.4 \\
1.3\end{array}$ & $\begin{array}{r}653 \\
69\end{array}$ & $\begin{array}{r}67 \\
6\end{array}$ \\
\hline
\end{tabular}

${ }^{*} \mathrm{~T}_{\mathfrak{j}}$ is half-time in days; $\boldsymbol{k}$ (turnover rate) is the fractional rate of renewal of the extrathyroidal organic iodine pool (EOI) per unit time.

t Erythrocyte sedimentation rate (ESR) elevated at the time the radiothyroxine disappearance study was performed.

$\ddagger$ Observations on radiothyroxine disappearance in nine hospital patients admitted for conditions other than rheumatoid arthritis-four with acne, two with chronic otitis media, two with minimal renal disease, and one with peripheral vascular disease.

returned to 11.0 per cent per day in the postsalicylate period. These findings approximate the accelerated fractional disappearance rate observed in thyrotoxicosis $(36,37)$. Moreover, the change in radiothyroxine disappearance is correlated with the increase in oxygen consumption ( $r=0.60$, $\mathrm{p}<0.01$ ) (Figure 3). Thus, the greater the increment in oxygen consumption the greater the increase in fractional rate of radiothyroxine disappearance from the circulation.

TABLE IIIB

Radiothyroxine disappearance in patients with rheumatoid arthritis during salicylate administration *

\begin{tabular}{|c|c|c|c|c|c|c|}
\hline \multirow[b]{2}{*}{ Subject } & \multirow[b]{2}{*}{ Weight } & \multirow[b]{2}{*}{ PBI } & \multicolumn{2}{|c|}{$\begin{array}{c}\text { Kinetics of } \\
\text { disappearance }\end{array}$} & \multirow{2}{*}{$\begin{array}{l}\text { Extrathyroidal } \\
\text { organic idoine } \\
\text { pool (EOI) }\end{array}$} & \multirow{2}{*}{$\begin{array}{c}\text { Degradation } \\
\text { rate }\end{array}$} \\
\hline & & & $\overline{t 1 / 2}$ & $\mathbf{k}$ & & \\
\hline $\begin{array}{l}\text { K. C. } \dagger \\
\text { R. P. } \\
\text { C. C. } \\
\text { F. C. } \\
\text { J. B. } \dagger \\
\text { R. B. } \\
\text { F. K. } \\
\text { W. C. } \\
\text { C. M. } \\
\text { T. K.† } \\
\text { J. L. } \\
\text { L. E. } \\
\text { R. Pi. } \\
\text { D. K. } \dagger \\
\text { G. D. } \dagger\end{array}$ & $\begin{array}{l}\mathrm{Kg} . \\
77.7 \\
76.8 \\
74.1 \\
76.4 \\
83.2 \\
58.2 \\
81.8 \\
65.9 \\
84.5 \\
57.7 \\
72.3 \\
61.4 \\
75.9 \\
64.1 \\
68.6\end{array}$ & $\begin{array}{c}\text { нg. } \% \\
4.4 \\
3.9 \\
3.7 \\
3.1 \\
4.6 \\
4.7 \\
3.1 \\
3.4 \\
3.4 \\
4.2 \\
3.2 \\
3.7 \\
4.0 \\
5.1 \\
4.5\end{array}$ & $\begin{array}{l}\text { days } \\
5.1 \\
5.3 \\
4.0 \\
3.4 \\
5.0 \\
4.9 \\
4.3 \\
4.4 \\
4.3 \\
4.0 \\
4.4 \\
5.0 \\
5.0 \\
5.1 \\
6.3\end{array}$ & $\begin{array}{l}\% / \text { day } \\
13.6 \\
13.1 \\
17.3 \\
20.4 \\
13.9 \\
14.2 \\
16.1 \\
15.8 \\
16.1 \\
17.3 \\
15.8 \\
13.9 \\
13.9 \\
13.6 \\
11.0\end{array}$ & $\begin{array}{c}\text { Mg./1.73 } M .2 \\
455 \\
502 \\
378 \\
317 \\
566 \\
474 \\
320 \\
399 \\
330 \\
479 \\
363 \\
325 \\
444 \\
619 \\
632\end{array}$ & $\begin{array}{c}\text { M. } .1 .73 M .2 / \text { day } \\
62 \\
66 \\
65 \\
65 \\
79 \\
67 \\
52 \\
63 \\
53 \\
83 \\
57 \\
45 \\
62 \\
84 \\
70\end{array}$ \\
\hline \multicolumn{2}{|c|}{$\begin{array}{l}\text { Mean } \\
\text { Standard deviation }\end{array}$} & $\begin{array}{l}3.9 \\
0.6\end{array}$ & $\begin{array}{l}4.7 \\
0.7\end{array}$ & $\begin{array}{r}15.1 \\
2.2\end{array}$ & $\begin{array}{l}440 \\
103\end{array}$ & $\begin{array}{l}65 \\
10\end{array}$ \\
\hline
\end{tabular}

* Radiothyroxine disappearance was measured after the PBI had fallen to a relatively constant value, i.e., after at least two weeks of salicylate administration and generally about the fourth week.

$\dagger$ ESR elevated at the time of the radiothyroxine study. 
TABLE IIIC

Radiothyroxine disappearance in patients with rheumatoid arthritis after discontinuation of salicylate administration *

\begin{tabular}{|c|c|c|c|c|c|c|}
\hline \multirow[b]{2}{*}{ Subject } & \multirow[b]{2}{*}{ Weight } & \multirow[b]{2}{*}{ PBI } & \multicolumn{2}{|c|}{$\begin{array}{c}\text { Kinetics of } \\
\text { disappearance }\end{array}$} & \multirow{2}{*}{$\begin{array}{l}\text { Extrathyroidal } \\
\text { organic iodine } \\
\text { pool (EOI) }\end{array}$} & \multirow{2}{*}{$\begin{array}{c}\text { Degradation } \\
\text { rate }\end{array}$} \\
\hline & & & t $1 / 2$ & $\mathbf{k}$ & & \\
\hline $\begin{array}{l}\text { K. C. } † \\
\text { R. P. } \\
\text { C. C. } \\
\text { F. C. } \\
\text { W. C. } \ddagger \\
\text { J. B. } \ddagger \\
\text { F. K. } \ddagger \\
\text { C. M. } \\
\text { J. L. } \\
\text { L. E. } \ddagger \\
\text { D. K. } \\
\text { G. D. }\end{array}$ & $\begin{array}{l}\text { Kg. } \\
71.8 \\
75.0 \\
74.1 \\
78.2 \\
59.1 \\
81.8 \\
82.7 \\
84.0 \\
74.1 \\
64.5 \\
70.5 \\
75.9\end{array}$ & $\begin{array}{l}\mu g . \% \\
5.3 \\
5.6 \\
5.4 \\
5.6 \\
4.5 \\
6.2 \\
5.4 \\
4.3 \\
4.8 \\
6.4 \\
5.6 \\
5.6\end{array}$ & $\begin{array}{l}\text { days } \\
6.6 \\
7.1 \\
7.5 \\
5.8 \\
5.9 \\
6.6 \\
6.0 \\
5.4 \\
6.0 \\
6.7 \\
6.3 \\
6.5\end{array}$ & $\begin{array}{c}\text { \%/day } \\
10.5 \\
9.8 \\
9.2 \\
12.0 \\
11.8 \\
10.5 \\
11.6 \\
12.8 \\
11.6 \\
10.3 \\
11.0 \\
10.7\end{array}$ & $\begin{array}{c}\text { Mg./1.73 } M .^{2} \\
545 \\
659 \\
510 \\
532 \\
487 \\
711 \\
550 \\
493 \\
505 \\
726 \\
600 \\
640\end{array}$ & 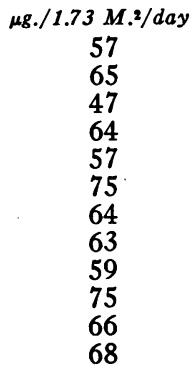 \\
\hline \multicolumn{2}{|c|}{$\begin{array}{l}\text { Mean } \\
\text { Standard deviation }\end{array}$} & $\begin{array}{l}5.4 \\
0.6\end{array}$ & $\begin{array}{l}6.4 \\
0.5\end{array}$ & $\begin{array}{r}11.0 \\
1.0\end{array}$ & $\begin{array}{r}580 \\
80\end{array}$ & $\begin{array}{r}63 \\
8\end{array}$ \\
\hline
\end{tabular}

* Radiothyroxine disappearance was measured two to four weeks after discontinuation of salicylate administration.

ESR elevated at time of radiothyroxine study.
$\ddagger$ Patients in whom radiothyroxine disappearance was studied both before (Table IIIa) and after salicylate administration.

The radiothyroxine distribution space showed no consistent change with chronic salicylate therapy, remaining unchanged in most patients, and increasing or decreasing slightly in an equal number of instances. Since the PBI concentration fell with salicylate treatment, the extrathyroidal organic iodine pool (EOI) was reduced to a mean of 440 micrograms from mean pre- and postsalicylate values of 598 and 581 micrograms, respectively. The degradation rate, being the product of the smaller EOI pool and the faster turnover rate, was found to be the same during salicylate administration as during the control periods, i.e., 67 micrograms per day per $1.73 \mathrm{M}^{2}$ before salicylates, 65 micrograms per day per $1.73 \mathrm{M}^{2}$ during salicylates, and 63 micrograms per day per $1.73 \mathrm{M} .^{2}$ after salicylate therapy.

To determine how quickly salicylate treatment increased the fractional rate of disappearance of radiothyroxine, the effect of acute salicylate administration was studied in four euthyroid patients and a fifth with myxedema seven days after injection of radiothyroxine. An increase in the fractional rate of disappearance of radiothyroxine from the circulation occurred within the first 24 hours of salicylate administration. However, it was not possible to calculate the degradation rate because steady state conditions did not prevail,

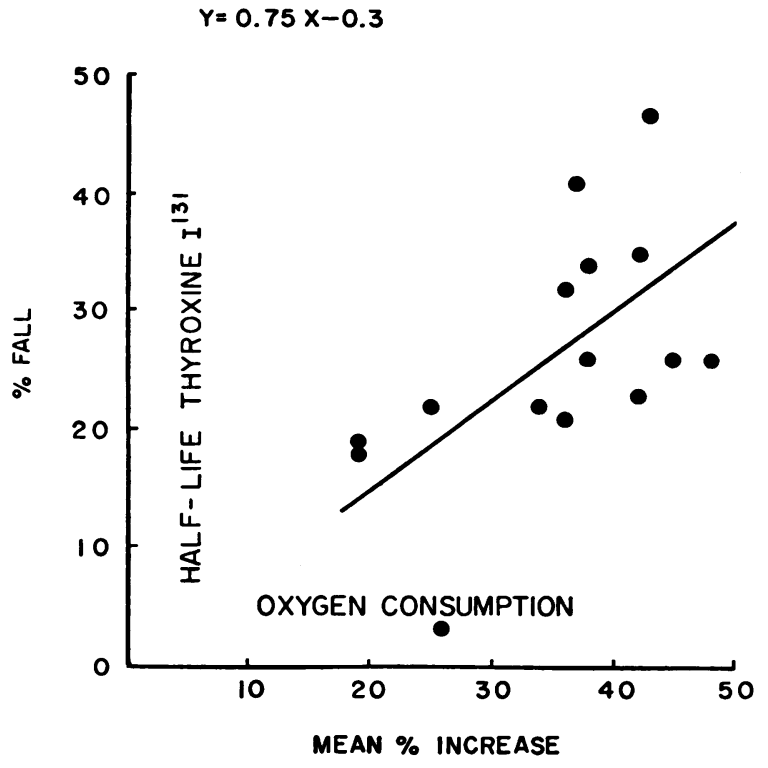

Fig. 3. Correlation of Oxygen Consumption and the Fractional Rate of I ${ }^{131}$ Disappearance

Per cent fall in half-life was obtained by comparing the half-life before or after salicylate administration with that during treatment. When both pre- and postsalicylate determinations were available (Table IIIc), they were averaged and the result compared to the value obtained during salicylate administration. The regression line is the best fit line through these points by the method of least squares. The coefficient of correlation ( $r$ ) is 0.60 $(\mathrm{p}<0.01)$. 
TABLE IV

The effect of salicylate therapy on the concentration of thyroxine binding sites of serum thyroxine-binding protein

\begin{tabular}{|c|c|c|c|c|c|c|c|c|c|}
\hline \multirow[b]{2}{*}{ Patient } & \multicolumn{3}{|c|}{ Before salicylate therapy } & \multicolumn{3}{|c|}{ During salicylate therapy* } & \multicolumn{3}{|c|}{ After salicylate therapy } \\
\hline & PBI & $\begin{array}{l}\text { TBP† } \\
\text { sites }\end{array}$ & $\begin{array}{c}\text { Free } \\
\text { T } \ddagger\end{array}$ & PBI & $\begin{array}{l}\text { TBP } \\
\text { sites }\end{array}$ & $\underset{T_{4}}{\text { Free }}$ & PBI & $\begin{array}{l}\text { TBP } \\
\text { sites }\end{array}$ & $\underset{T_{4}}{\text { Free }}$ \\
\hline $\begin{array}{l}\text { R. P. } \\
\text { T. K. } \\
\text { K. C. } \\
\text { W. C. } \\
\text { F. K. } \\
\text { J. L. }\end{array}$ & 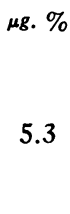 & $2.8 \times 10^{-7} \mathrm{M}$ & $6.0 \times 10^{-11} \mathrm{M}$ & $\begin{array}{c}\mu g . \% \\
3.4 \\
4.4 \\
3.8 \\
3.4 \\
3.1 \\
3.0\end{array}$ & $\begin{array}{l}2.1 \times 10^{-7} \mathrm{M} \\
1.9 \\
3.1 \\
2.8 \\
2.3 \\
2.0\end{array}$ & $\begin{array}{l}4.6 \times 10^{-11} \mathrm{M} \\
5.5 \\
3.5 \\
3.2 \\
3.7 \\
4.1\end{array}$ & $\begin{array}{c}\mu g . \% \\
4.4 \\
7.2 \\
6.6 \\
4.5 \\
5.4 \\
4.8\end{array}$ & $\begin{array}{l}2.1 \times 10^{-7} \\
2.3 \\
2.8 \\
2.5 \\
2.4 \\
2.1\end{array}$ & $\begin{array}{l}6.6 \times 10^{-11} \mathrm{M} \\
8.9 \\
8.4 \\
4.7 \\
7.3 \\
6.7\end{array}$ \\
\hline Mean & & & & 3.5 & 2.4 & 4.1 & 5.5 & 2.4 & 7.1 \\
\hline
\end{tabular}

* Thyroxine binding was studied after four to eight weeks of salicylate therapy and again four to six weeks after discontinuation of salicylate treatment.

$\dagger$ TBP refers to thyroxine-binding protein.

$\ddagger T_{4}$ refers to free thyroxine calculated according to Robbins and Rall (38).

i.e., the EOI pool was not known because the PBI was falling and the distribution space was not determined.

\section{Thyroxine binding}

The major portion of thyroxine is normally bound in the plasma to a specific thyroxine binding alpha-globulin (TBP) (38). A decrease in the amount of this protein, a change in the affinity constant for thyroxine, or competition by salicylate or one of its conjugates for the binding sites would reduce the per cent of bound thyroxine and possibly change thyroxine metabolism. Salicylate administration was not associated with any sig- nificant alteration in the concentration of TBP sites (Table IV). Hence, free thyroxine falls concomitantly with the decrease in PBI. Furthermore, there was no alteration in the distribution of thyroxine among the serum proteins when only small quantities of thyroxine were used, suggesting that, with physiologic thyroxine concentrations, there was no effective competition for binding sites between salicylate and thyroxine. Thus, a change in the binding of radiothyroxine is not the explanation for the increased fractional rate of disappearance of radiothyroxine. The present situation appears to be an exception to the dependence of the degradation rate upon the level of free thyroxine as postulated by Robbins and Rall (38).

TABLE V

Effect of salicylates on thyroid uptake of $I^{131}$

\begin{tabular}{|c|c|c|c|c|c|c|c|c|c|}
\hline \multirow[b]{3}{*}{ Patient } & \multicolumn{9}{|c|}{ Per cent of administered dose in thyroid } \\
\hline & \multicolumn{3}{|c|}{ Control period } & \multicolumn{3}{|c|}{ Salicylate period } & \multicolumn{3}{|c|}{ Postcontrol period } \\
\hline & $2 \mathrm{hr}$. & $5 \mathrm{hr}$. & $24 \mathrm{hr}$. & $2 \mathrm{hr}$. & $5 \mathrm{hr}$. & $24 \mathrm{hr}$. & $\overline{2 \mathrm{hr} .}$ & $5 \mathrm{hr}$. & $24 \mathrm{hr}$. \\
\hline $\begin{array}{l}\text { K. C. } \\
\text { C. C. } \\
\text { W. C. } \\
\text { J. B. } \\
\text { R. B. } \\
\text { F. K. } \\
\text { C. M. } \\
\text { J. L. } \\
\text { R. Pi. }\end{array}$ & $\begin{array}{r}17 \\
13 \\
10 \\
17 \\
12 \\
13 \\
6 \\
5 \\
10\end{array}$ & $\begin{array}{l}23 \\
25 \\
16 \\
23 \\
17 \\
20 \\
11 \\
10 \\
17\end{array}$ & $\begin{array}{l}38 \\
50 \\
26 \\
34 \\
30 \\
29 \\
18 \\
16 \\
33\end{array}$ & $\begin{array}{r}3 \\
8 \\
6 \\
5 \\
5 \\
7 \\
3 \\
3 \\
11\end{array}$ & $\begin{array}{r}7 \\
17 \\
9 \\
8 \\
8 \\
12 \\
5 \\
4 \\
17\end{array}$ & $\begin{array}{r}19 \\
26 \\
17 \\
15 \\
15 \\
21 \\
9 \\
6 \\
27\end{array}$ & $\begin{array}{r}9 \\
15 \\
8 \\
10 \\
\\
10 \\
6 \\
4\end{array}$ & $\begin{array}{r}13 \\
21 \\
13 \\
13 \\
\\
14 \\
8 \\
9\end{array}$ & $\begin{array}{l}31 \\
43 \\
20 \\
25 \\
\\
\\
24 \\
14 \\
16\end{array}$ \\
\hline \multirow{2}{*}{$\begin{array}{l}\text { Mean } \\
\text { Standard } \\
\text { deviation }\end{array}$} & 11 & 18 & 30 & 6 & 10 & 17 & 9 & 13 & 25 \\
\hline & 4 & 5 & 10 & 2 & 4 & 7 & 3 & 4 & 9 \\
\hline
\end{tabular}




\section{Radioiodine studies}

The possibility that the reduction in PBI was in part due to a depression in thyroid function and ultimately in hormone synthesis was explored in several ways. The 2,5 and 24 -hour thyroid radioiodine uptake was observed in nine patients before and during salicylate therapy, and in seven of these patients six weeks after discontinuing the drug (Table V). The mean fall in uptake was 45 per cent of the control value at 2 hours, 44 per cent at 5 hours, and 43 per cent at 24 hours; in comparison to the postsalicylate values the reduction in uptake was less, but still 33,23 and 36 per cent at 2,5 and 24 hours, respectively. Serial determinations were not performed but the reduction recorded in Table $\mathrm{V}$ was observed after two weeks in Patient C. M., after four weeks in Patients K. C. and J. L., and after eight weeks in the remainder.

The kidney is the chief organ competing with the thyroid gland for circulating iodide. Thus, an increase in the renal clearance of $\mathrm{I}^{131}$ could produce an apparent depression of thyroid uptake. That this was not the case is shown in Figure 4. No change in the renal clearance of iodide occurred during salicylate administration, the mean clearance being $53 \mathrm{ml}$. per minute both on and off salicylate therapy. This value is slightly higher than that usually observed (39-41). Bricker and Hlad (41) have demonstrated that a water diuresis up to $6 \mathrm{ml}$. per minute does not alter renal clearance of radioiodine, but they did not carry the diuresis to the rates of urine flow used in the present study.

On the other hand, thyroid clearance of radioiodide was reduced in each patient during chronic salicylate administration (Figure 4). This indicates that the diminution in radioiodine uptake (Table V) is indeed an expression of depressed thyroid function. The control thyroid clearance and the radioiodine distribution space before and during salicylate therapy agree with the values reported by Berson, Yalow, Sorrentino, and Roswit (40).

The reduction in thyroid uptake and clearance of radioiodine during chronic salicylate administration could result either from inhibition of the iodide concentrating mechanism or from interference with the utilization of the accumulated io-
PERIOD

CONTROL

SALICYLATE

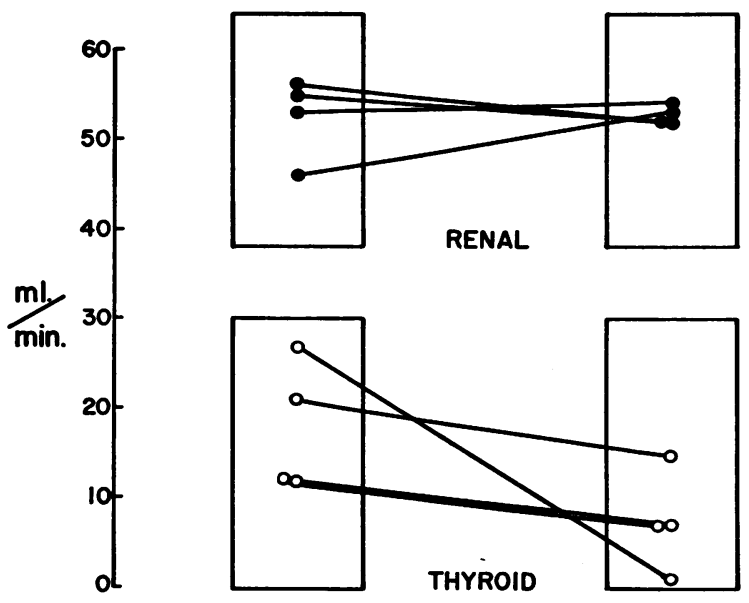

Fig. 4. Effect of Salicylate Administration on $I^{131}$ Clearance

The clearance determinations were done after six weeks of salicylate administration; in three subjects the control value was obtained before salicylate treatment, and in the other the control study was done four weeks after discontinuation of salicylates. Each point represents the mean of six or more clearance values obtained at halfhour intervals.

dide for hormone synthesis. The former possibility is conveniently measured in rats as the concentration gradient of iodide in the thyroid to that in the serum or plasma ( $\mathrm{T} / \mathrm{S}$ ratio) when hormone synthesis is blocked. Even at high serum concentrations acute salicylate administration does not depress the ability of the rat thyroid to concentrate iodide (Table VI). In contrast, sodium thiocyanate produced the expected marked depression of the $\mathrm{T} / \mathrm{S}$ ratio.

Para-hydroxy benzoic acid may interfere with thyroidal organification of iodide (42). Thus,

TABLE VI

Effect of salicylate and thiocyanate on the thyroid/serum iodide ratio in rats

\begin{tabular}{ccc}
\hline \hline Treatment & $\begin{array}{c}\text { Mean } \\
\text { blood level }\end{array}$ & $\begin{array}{c}\text { Mean } \\
\text { T/S ratio }\end{array}$ \\
\hline Control (15)* & $m g . \%$ & $147 \pm 10 \dagger$ \\
Salicylate (15) & $51(15)^{*}$ & $\begin{array}{l}137 \pm 8 \\
\text { Na SCN (12) }\end{array}$ \\
\end{tabular}

* Figures in parentheses refer to the number of rats used.

$\dagger$ Mean \pm standard error. The " $t$ " test reveals that the salicylate treated rats do not differ significantly from the control $(0.5>\mathrm{p}>0.4)$. 
the possibility that salicylic acid might have a similar action was evaluated using rat thyroid slices. A concentration of $3 \times 10^{-3} \mathrm{M}$ salicylate (41 mg. per cent) did not interfere with the ability of thyroid slices to convert incorporated iodide to organic forms (Table VII); in contrast, 1-methyl2-mercaptoimidazole almost completely inhibited the organification of the iodide. There was a slight decrease in the incorporation of the iodide into the slices in the presence of a concentrated salicylate solution as compared to the incorporation in the Krebs-Ringer media. However, when comparison was made using sera from salicylate treated patients as the incubation medium, salicylates did not diminish incorporation (Table VII). This is not surprising since at these levels about 70 per cent of the salicylate is bound to plasma protein (43-45). The possibility of thyroid inhibition by some salicylate derivative is thus also excluded. Furthermore, the addition of known amounts of buffered sodium salicylate in the concentration

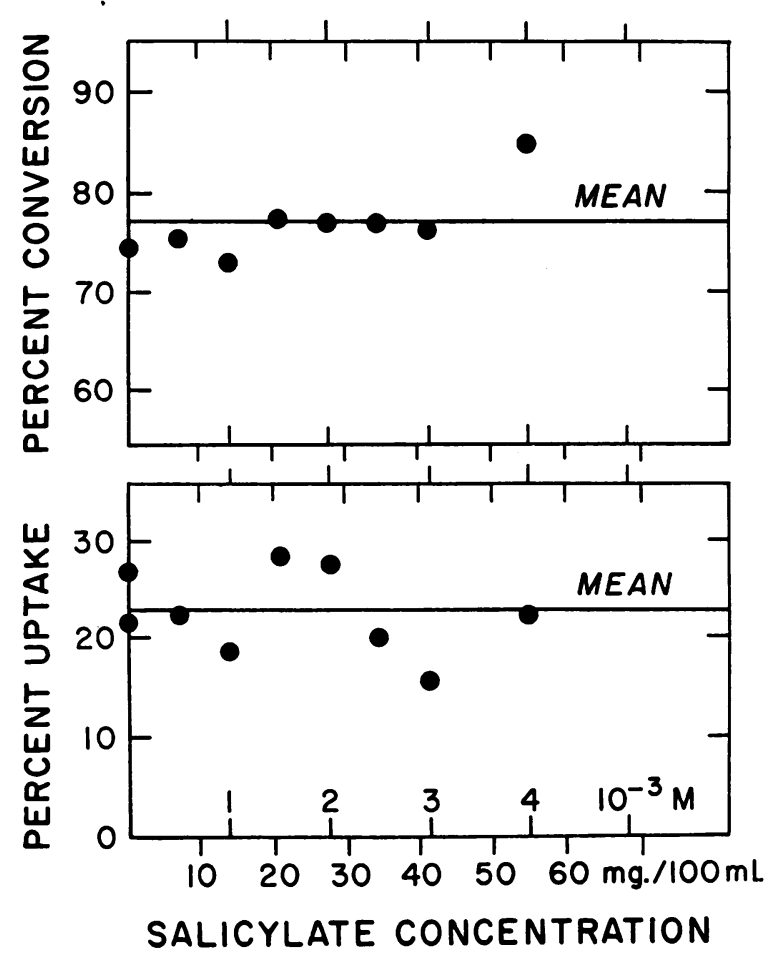

Fig. 5. EFFect of Salicylate on the Uptake and Organification of I ${ }^{181}$ by Rat Thyroid Slices

Rat thyroid tissue was incubated in human serum to which varying concentrations of buffered sodium salicylate were added. obtained clinically in this study had no direct effect on the uptake and organification of radioiodine by rat thyroid slices (Figure 5 ).

\section{COMMENT}

An increase in the basal metabolic rate associated with a negative nitrogen balance and weight loss on a fixed caloric intake can be produced in euthyroid patients by salicylate administration. In patients with myxedema the serum cholesterol is also lowered by salicylate treatment. On the other hand, the clinical findings generally regarded as characteristic of hyperthyroid hypermetabolism, such as heat intolerance, hyperkinesis, emotional lability, and tachycardia, are lacking.

Concomitant with the increase in oxygen consumption, salicylate administration produces a prompt reduction in the serum protein bound iodine concentration. The abrupt decrease in the rate of release of thyroidal $\mathrm{I}^{\mathrm{Is}}$ with salicylate administration (46) probably contributes significantly to the rapid fall in the PBI. On the other hand, the depression in the thyroidal uptake and clearance of $\mathrm{I}^{131}$ probably does not play an important role in the early reduction of the PBI because of the large stores of stable iodine in the normal gland. Whatever the contributing causes, a new steady state is attained within the first 10

TABLE VII

The effect of salicylate on the uptake and conversion of $I^{131}$ by rat thyroid slices*

\begin{tabular}{|c|c|c|c|}
\hline $\begin{array}{l}\text { Experi- } \\
\text { ment }\end{array}$ & Incubation medium & $\begin{array}{l}\text { Per cent } \\
\text { of total } \\
\text { I }^{181} \text { in } \\
\text { slices }\end{array}$ & $\begin{array}{c}\text { Per cent } \\
\text { of slice } \\
\text { Ir1 as } \\
\text { organic } \\
I_{131}\end{array}$ \\
\hline \multirow{4}{*}{ I } & Krebs-Ringer phosphate & 62 & 86 \\
\hline & salicylate & 54 & 70 \\
\hline & salicylate & 47 & 78 \\
\hline & $\begin{array}{l}1 \times 10^{-3} \text { M 1-methyl- } \\
\text { 2-mercaptoimidazole }\end{array}$ & 40 & 1.0 \\
\hline \multirow[b]{2}{*}{ II } & Normal human serum & 48 & 85 \\
\hline & $\begin{array}{l}\text { Salicylate serum } \\
\quad\left(41 \mathrm{mg} . \% \text { or } 3 \times 10^{-3} \mathrm{M}\right)\end{array}$ & 44 & 75 \\
\hline
\end{tabular}

* Forty mg. of slices from thyroids of rats kept on a low iodine diet for 26 days, incubated at $37^{\circ} \mathrm{C}$. for three hours in $3.0 \mathrm{ml}$. of Krebs-Ringer phosphate medium, $\mathrm{pH} \mathrm{7.4,}$ containing the agents indicated. In Experiment II serum from patients before and during salicylate therapy was used in place of the Krebs-Ringer phosphate medium. 
days of salicylate administration, and the PBI is not lowered to frankly hypothyroid levels.

In view of the finding of a normal degradation rate together with depressed thyroid function during chronic salicylate treatment, the failure of the PBI to continue to fall is at present not readily explained. This disparity could result from a methodological artifact in the estimation of the degradation rate, for it can be shown (47) that under certain circumstances in open systems calculation of pool size by the intercept method contains an error that is proportional to the slope. Furthermore, Ingbar and Freinkel (37) noted a discrepancy between the amount of thyroid hormone synthesized and degraded, calculated by independent means, in patients with hypermetabolism due to thyrotoxicosis. Sterling and Chodos (36) observed an increased fractional rate of disappearance of radiothyroxine, a normal PBI, an enlarged EOI pool, and an increased degradation rate in patients with hypermetabolism of malignancy and infection. If the augmented degradation rate continued for a period of time, the thyroidal stores of $\mathrm{I}^{127}$ would become depleted and an increase in the thyroidal uptake of $\mathrm{I}^{131}$ might be expected. This, however, was not observed in the patients with leukemia and other causes of extrathyroidal hypermetabolism studied by Meckstroth, Rapport, Curtis, and Simcox (48) and by Skanse (49). Thus, extrathyroidal hypermetabolism due to malignancy and infection may be another example of a disparity between peripheral thyroxine metabolism, measured by the intercept method, and the level of function of the thyroid gland, as measured by thyroidal uptake, clearance, or release rate.

The failure of acute salicylate administration to reduce the $T / S$ ratio in the rat or to interfere with the incorporation and organification of $\mathrm{I}^{131}$ by rat thyroid slices suggests that thyroid inhibition is not the result of a direct effect of salicylate on the thyroid gland. An indirect action, presumably via the pituitary or higher centers, similar to that of thyroxine is suggested. The localization of this indirect inhibition and the implication of a decrease in available thyrotropin form the subject of the following report (46).

\section{SUMMARY}

1. The effect of salicylate administration was studied in 24 euthyroid patients and 1 patient with myxedema; 19 received 6.0 to $8.1 \mathrm{Gm}$. of sodium salicylate per day for 8 to 15 weeks and 6 were given $9.0 \mathrm{Gm}$. per day for 7 to 10 days.

2. Oxygen consumption during chronic salicylate therapy (mean concentration, $37 \mathrm{mg}$. per 100 $\mathrm{ml}$.) was increased 33 per cent (from 221 to 294 $\mathrm{ml}$. per min. per $1.73 \mathrm{M.}^{2}$ ). There was a significant correlation $(r=0.72, p<0.01)$ between the increase in oxygen consumption and the serum salicylate concentration.

3. The serum protein bound iodine concentration was reduced from a mean of 5.5 to 3.8 micrograms per $100 \mathrm{ml}$. during chronic salicylate administration and was maintained at this level until the salicylate was discontinued.

4. The fractional rate of disappearance of radiothyroxine from the circulation rose from a mean of 11.3 per cent per day to 15.1 per cent per day during chronic salicylate therapy and returned to 11.0 per cent per day with cessation of salicylate treatment. There was a significant correlation $(r=0.60, p<0.01)$ between the increase in the fractional rate of radiothyroxine disappearance and the rise in oxygen consumption.

5. The mean reduction in 2,5 and 24 hour uptake of radioiodine during chronic salicylate treatment was 45 per cent of the control value at 2 hours, 44 per cent at 5 hours, and 43 per cent at 24 hours.

6. Thyroidal clearance of radioiodine was depressed in four patients during chronic salicylate administration whereas renal clearance was not significantly altered.

7. Acute salicylate administration in rats did not reduce the thyroid/plasma ratio of radioiodine.

8. The incubation of rat thyroid slices in serum of salicylate-treated patients did not interfere with the incorporation or organification of radioiodine.

9. These findings suggest that an important action of salicylate administration is a depression of thyroid function, presumably via the pituitary or higher centers.

\section{ACKNOWLEDGMENTS}

We wish to thank Lt. Col. E. A. Langdon for advice and assistance, and Captain Emma Stapleton, Miss Anne Berman, and M/Sgt. F. Serwacki for technical assistance. 
We would also like to thank Dr. J. E. Rall for suggesting the technique employed to obtain the corrected neck counts used in the thyroid clearance calculation, Dr. J. R. Robbins. for his aid in the determinations of the thyroxine-binding capacity, and Dr. C. G. Lewallen for advice regarding the kinetics of radiothyroxine disappearance.

\section{REFERENCES}

1. Denis, W., and Means, J. H. The influence of salicylate on metabolism in man. J. Pharmacol. exp. Ther. 1916, 8, 273.

2. Cochran, J. B. The respiratory effects of salicylate. Brit. med. J. 1952, 2, 964.

3. Cochran, J. B. Further observations on the metabolic stimulating effect of salicylate. Brit. med. J. 1954, 1, 733.

4. Meade, B. W. The effect of certain hydroxybenzoic acids on the oxygen consumption of Wistar rats. Ann. rheum. Dis. 1954, 13, 60.

5. Tenney, S. M., and Miller, R. M. The respiratory and circulatory actions of salicylate. Amer. J. Med. 1955, 19, 498.

6. Reid, J. A new outlook on the action of salicylate. Scot. med. J. 1957, 2, 91.

7. Brody, T. M. The action of sodium salicylate and related compounds on tissue metabolism in vitro. J. Pharmacol. exp. Ther. 1956, 117, 39.

8. Sproull, D. H. A peripheral action of sodium salicylate. Brit. J. Pharmacol. 1954, 9, 262.

9. Smith, M. J. H., and Jeffrey, S. W. The effect of salicylate on oxygen consumption and carbohydrate metabolism in the isolated rat diaphragm. Biochem. J. 1956, 63, 524.

10. Cutting, W. C., Rytand, D. A., and Tainter, M. L. Relationship between blood cholesterol and increased metabolism from dinitrophenol and thyroid. J. clin. Invest. 1934, 13, 547.

11. Alwall, N., and Scheff-Pfeifer, I. Uber den Synergismus Dinitrophenol-Thyroxin und Methylen blau-thyroxin am künstlich durchströmten isolierten Hundebein. Naunyn-Schmiedeberg's Arch. exp. Path. Pharmak. 1936, 184, 296.

12. Simkins, S. Dinitrophenol and desiccated thyroid in the treatment of obesity. J. Amer. med. Ass. 1937, 108, 2110 and 2193.

13. Goldberg, R. C., Wolff, J., and Greep, R. O. Studies on the nature of the thyroid-pituitary interrelationship. Endocrinology 1957, 60, 38.

14. Lardy, H. A., and Wellman, H. Oxidative phosphorylations: Role of inorganic phosphate and acceptor systems in control of metabolic rates. J. biol. Chem. 1952, 195, 215.

15. Packer; L. Coupled phosphorylation in rat heart muscle sarcosomes. Arch. Biochem. 1957, 70, 290.

16. Smith, M. J. H., Meade, B. W., and Bornstein, J. The effect of salicylate on glycosuria, blood glucose, and liver glycogen of the alloxan-diabetic rat. Biochem. J. 1952, 51, 18.
17. Wolff, J., Rubin, L., and Chaikoff, I. L. The influence of 2,4-dinitrophenol on plasma proteinbound iodine. J. Pharmacol. exp. Ther. 1950, 98, 45.

18. Goldberg, R. C., Wolff, J., and Greep, R. O. The mechanism of depression of plasma protein bound iodine by 2,4-dinitrophenol. Endocrinology 1955, $56,560$.

19. Castor, C. W., and Beierwaltes, W. The effect of 2,4-dinitrophenol on thyroid function in man. J. clin. Endocr. 1956, 16, 1026.

20. Austen, F. K., Rubini, M. E., Meroney, W. H., and Wolff, J. Salicylates and thyroid function (abstract). J. clin. Invest. 1957, 36, 870.

21. Keller, W. J., Jr. A rapid method for the determination of salicylates in serum or plasma. Amer. J. clin. Path. 1947, 17, 415.

22. Peters, J. H. The determination of creatinine and creatine in blood and urine with the photoelectric colorimeter. J. biol. Chem. 1942, 146, 179.

23. Smith, P. K. Certain aspects of the pharmacology of the salicylates. Pharmacol. Rev. 1949, 1, 353.

24. Smith, P. K. Review of pharmacology and metabolism of aspirin and salicylic acid in Aspirin-Recent Advances in its Pharmacology and Clinical Use. St. Louis, Monsanto Chemical Company, 1956, p. 1.

25. Schoenheimer, R., and Sperry, W. M. A micromethod for the determination of free and combined cholesterol. J. biol. Chem. 1934, 106, 745.

26. Pearson, S., Stern, S., and McGavack, T. H. A rapid, accurate method for the determination of total cholesterol in serum. Analyt. Chem. 1953, $25,813$.

27. Barker, S. B., Humphrey, M. J., and Soley, M. H. The clinical determination of protein-bound iodine. J. clin. Invest. 1951, 30, 55.

28. Sterling, K., Lashof, J. C., and Man, E. B. Disappearance from serum of $\mathrm{I}^{111}$-labeled 1-thyroxine and 1-triiodothyronine in euthyroid subjects. J. clin. Invest. 1954, 33, 1031.

29. Robbins, J. Reverse-flow zone electrophoresis. A method for determining the thyroxine-binding capacity of serum protein. Arch. Biochem. 1956, 63, 461.

30. Keating, F. R., Jr., Wang, J. C., Luellen, T. J., Williams, M. M. D., Power, M. H., and McConahey, W. M. The measurement of the iodine-accumulating function of the human thyroid gland. J. clin. Invest. 1949, 28, 217.

31. Morton, M. E., and Chaikoff, I. L. The formation in vitro of thyroxine and diiodotyrosine by thyroid tissue with radioactive iodine as indicator. J. biol. Chem. 1943, 147, 1.

32. Alexander, W. D., and Johnson, K. W. M. Comparison of the metabolic stimulating action of aspirin and thyroid. Nature (Lond.) $1956,178,259$.

33. Austen, F. K., Rubini, M. E., and Meroney, W. H. 
The effect of salicylate administration on nitrogen, calcium, and phosphorus balance. In preparation.

34. Alexander, W. D., and Johnson, K. W. A comparison of the effects of acetylsalicylic acid and DL-triiodothyronine in patients with myxoedema. Clin. Sci. 1956, 15, 593.

35. Stamler, J., Silber, E. N., Miller, A. J., Akman, L., Bolene, C., and Katz, L. N. The effect of thyroidand of dinitrophenol-induced hypermetabolism on plasma and tissue lipids and atherosclerosis in the cholesterol-fed chick. J. Lab. clin. Med. 1950, 35, 351.

36. Sterling, K., and Chodos, R. B. Radiothyroxine turnover studies in myxedema, thyrotoxicosis, and hypermetabolism without endocrine disease. J. clin. Invest. 1956, 35, 806.

37. Ingbar, S. H., and Freinkel, N. Simultaneous estimation of rates of thyroxine degradation and thyroid hormone synthesis. J. clin. Invest. 1955, 34, 808.

38. Robbins, J., and Rall, J. E. The interaction of thyroid hormones and protein in biological fluids. Recent Progr. Hormone Res. 1957, 13, 161.

39. Myant, N. B., Pochin, E. E., and Goldie, E. A. G. The plasma iodide clearance rate of the human thyroid. Clin. Sci. 1949, 8, 109.

40. Berson, S. A., Yalow, R. S., Sorrentino, J., and Roswit, $B$. The determination of thyroidal and renal plasma $I^{131}$ clearance rates as a routine diagnostic test of thyroid dysfunction. J. clin. Invest. 1952, $31,141$.

41. Bricker, N. S., and Hlad, C. J., Jr. Observations on the mechanism of the renal clearance of $\mathrm{I}^{131}$. J. clin. Invest. 1955, 34, 1057.

42. Taurog, A., Chaikoff, I. L., and Franklin, A. L. The structural specificity of sulfanilamide-like compounds as inhibitors of the in vitro conversion of inorganic iodide to thyroxine and diiodotyrosine by thyroid tissue. J. biol. Chem. 1945, 161, 537.

43. Smith, P. K., Gleason, H. L., Stoll, C. G., and Ogorzalek, S. Studies on the pharmacology of salicylates. J. Pharmacol. exp. Ther. 1946, 87, 237.

44. Lester, D., Lolli, G., and Greenberg, L. A. The fate of acetylsalicylic acid. J. Pharmacol. exp. Ther. 1946, 87, 329.

45. Seeberg, V. P., Hansen, D., and Whitney, B. Absorption and distribution of salicylamide. J. Pharmacol. exp. Ther. 1951, 101, 275.

46. Wolff, J., and Austen, F. K. Salicylates and thyroid function. II. The effect on the thyroid-pituitary interrelation. J. clin. Invest. 1958, 37, 1144.

47. Lewallen, C. G., and Berman, M. Personal communication.

48. Meckstroth, C. V., Rapport, R. L., Curtis, G. M., and Simcox, S. J. The laboratory diagnosis of extrathyroidal hypermetabolism. J. clin. Endocr. 1952, 12, 1373.

49. Skanse, B. Radioactive iodine in the diagnosis of thyroid disease. Acta med. scand. 1949, Suppl. 235. 